\title{
In vitro induction of melanin synthesis and extrusion by tamoxifen
}

\author{
T. Matamá*, ${ }^{\dagger}$, R. Araújo ${ }^{* \dagger}$, A. Preto*, A. Cavaco-Paulo ${ }^{\dagger}$ and A. C. Gomes* \\ *CBMA (Centre of Molecular and Environmental Biology), Department of Biology, University of Minho, Campus of Gualtar, 4710-057, Braga, \\ Portugal and ${ }^{\dagger} \mathrm{IBB}$ - Institute for Biotechnology and Bioengineering, Centre of Biological Engineering, University of Minho, Campus de Gualtar, \\ 4710-057, Braga, Portugal
}

Received 01 February 2013, Accepted 06 April 2013

Keywords: catalase, cell culture, colour cosmetics, genetic analysis, SERM, skin pigmentation

\begin{abstract}
Synopsis.
OBJECTIVES: Physical appearance has significant importance psychologically and socially, with skin and hair being of prime relevance. Effective ingredients that modulate melanin synthesis are of growing interest. Tamoxifen, a widely used selective oestrogen receptor modulator, SERM, was described occasionally in medical case reports as causing grey hair repigmentation. This work aimed to study, in vitro, the effect of tamoxifen and 4-hydroxy-tamoxifen, one of its most bioactive derivatives, on melanin production in human melanocytes.
\end{abstract}

METHODS: Adult normal human epidermal melanocytes (NHEM) were treated with physiological concentrations of tamoxifen and 4hydroxy-tamoxifen during 72 hours. Cytotoxicity was evaluated by lactate dehydrogenase (LDH) leakage. Total melanin was quantified by spectrophotometry, and cyclic adenosine monophosphate (cAMP) was determined by competitive ELISA. The relative mRNA levels of several genes involved in melanogenesis were investigated by real-time PCR.

RESULTS: Under the conditions used, the results showed that tamoxifen and 4-hydroxy-tamoxifen treatments, none of them toxic to NHEM, induced a time-dependent increase in the amount of melanin released to the culture medium. cAMP, one of the major second messenger in signalling pathways important to melanogenesis, was decreased after treatment. The transcript levels of genes coding for catalase, premelanosome protein and melan-A, directly related to skin and hair pigmentation, showed an increased tendency upon tamoxifen and 4-hydroxy-tamoxifen treatment. Induction of catalase gene expression in NHEM points towards a promelanogenic effect mediated by ROS.

CONCLUSION: According to the results, even in such a short treatment period, tamoxifen and 4-hydroxy-tamoxifen promoted melanin extrusion and they seem to act as melanogenesis stimulators at the molecular level. Our data suggest that SERMs might be a new tool for increasing melanogenesis and might be of great interest for topical formulations in cosmetic industry.

\section{Résumé.}

OBJECTIF: L'apparence physique a une grande importance psychologique et sociale, la peau et les cheveux étant d'un intérêt primor-

Correspondence: Prof. Andreia C Gomes, CBMA (Centre of Molecular and Environmental Biology), Department of Biology, University of Minho, Campus of Gualtar, 4710-057 Braga, Portugal. Tel.: +351 253601511 ; fax: +351253678980; e-mail: agomes@bio.uminho.pt dial. Les ingrédients efficaces qui modulent la synthèse de mélanine sont d'un intérêt croissant. Le tamoxifène, un modulateur sélectif des récepteurs d'oestrogène largement utilisé (SERM), a été décrit dans les rapports de cas médicaux comme causant une re-pigmentation des cheveux gris. Ce travail visait à étudier, in vitro, l'effet du tamoxifène et du 4-hydroxy-tamoxifène, un de ses dérivés les plus bioactifs, sur la production de mélanine dans les mélanocytes de l'homme.

METHODES: Des mélanocytes épidermiques adulte humains normaux (NHEM) ont été traités avec des concentrations physiologiques de tamoxifêne et de 4-hydroxy-tamoxifène pendant 72 heures. La cytotoxicité a été évaluée par la sécrétion de la lactate-déshydrogénase (LDH). La mélanine totale a été quantifiée par spectrophotométrie et l'adénosine monophosphate cyclique (AMPc) a été déterminée par ELISA. Les niveaux relatifs d'ARNm de plusieurs gènes impliqués dans la mélanogénèse ont été étudiés par PCR en temps réel.

RESULTATS: Dans les conditions utilisées, les résultats ont montré que les traitements au tamoxifène et au 4-hydroxy-tamoxifène, aucun d'entre eux n'étant toxique pour les NHEM, induisent une augmentation en fonction du temps, de la quantité de mélanine libérée dans le milieu de culture. L'AMPc, un des messagers sécondaires importants dans les voies de signalisation principales de la mélanogénèse, a diminué après le traitement. Les niveaux de transcription des gènes codant pour la catalase, la protéine pré-mélanosome et mélan- $A$, directement liées à la pigmentation de la peau et des cheveux, ont montré une tendance à l'augmentation par le tamoxifêne et le 4-hydroxy-tamoxifène. L'induction de l'expression du gène de la catalase dans les NHEM pointe vers un effet pro-mélanogénique médié par les ROS.

CONCLUSION: Selon les résultats, même dans une période de traitement de courte durée, le tamoxifène et le 4-hydroxy-tamoxifène promeuvent l'extrusion de la mélanine et ils semblent agir comme stimulateurs de la mélanogénèse au niveau moléculaire. Nos données suggèrent que les SERMs pourraient devenir un nouvel outil pour augmenter la mélanogénèse et peut-être avoir un grand intérêt pour les formulations topiques dans l'industrie cosmétique.

\section{Introduction}

In today's society, the concern with preserving a good physical appearance feeds a huge industry of cosmetic products, with skin and its appendages (hair in particular) being the primary targets. 
Oestrogens play important protective roles in skin physiology and ageing [1]. They accelerate wound healing, improve inflammatory skin conditions and provide protection to skin photoageing [2]. The beneficial effects are confirmed by the changes seen in post-menopausal women when a rapid skin age-related deterioration is observed - thinner and drier skin, more and deeper wrinkles, loss of skin firmness and elasticity [2]. Topical application of oestrogens and hormonal replacement therapies can reverse at some extent these skin age-related events. The effect of oestrogens in human hair cycle is not so obvious; they appear to stimulate hair growth by decreasing the resting phase and by prolonging the anagen phase, especially in women; it was demonstrated that oestrogen has the ability to modify androgen metabolism in dermal papillae of hair follicles [3]. Oestrogens also affect skin pigmentation. High oestrogen levels are associated with an increase in skin pigmentation particularly evident during pregnancy and during the use of oestrogen-containing oral contraceptives. Topical application of oestrogens was described as having no significant effect on pigmentary changes in aged skin [4]. In in vitro studies, some apparent conflicting reports have been published; McLeod et al. [5] reported that melanocytes respond to oestrogens, in particular to $17 \beta$-oestradiol, with increased melanin production and extrusion, whereas Jee et al. [6] reported an increase in melanocyte proliferation with a concomitant decrease in melanin levels and tyrosinase activity. More, recently, it was demonstrated in vitro that the oestrogen receptor $\alpha$ is an activator of dopachrome tautomerase gene $(D C T)$ promoter activity in cooperation with additional transcription factors and microphthalmia-associated transcription factor (MITF) in normal human melanocytes [7].

Since the discovery in the 1990s that skin expresses oestrogen receptors that decline in number from the onset of menopause, the search for safe and effective alternatives with more focused effects on the skin, topical oestrogens, phyto-oestrogens and tissue-specific drugs called selective oestrogen receptor modulators (SERMs) has been explored $[8,9]$. SERMs bind to oestrogen receptors and can act as either oestrogen agonists or antagonists depending on the target tissue. Tamoxifen, a non-steroidal triphenylethylene, is a SERM widely used, since 1971, in the management of women with all stages hormone-responsive breast cancer [10]. Although the effects of oestrogens on skin are extensively documented, there are very limited data on the effect of SERMs on this organ. Topical tamoxifen improves the appearance of keloid scars in acute burns patients, fading fibroblast proliferation and collagen synthesis [1]. SERMs tamoxifen, raloxifene and genistein all substantially benefit skin healing in the oestrogen-deprived ovariectomized mouse, most likely mediated via oestrogen receptor $\beta$ [1]. In contrast, a subcutaneous administration of tamoxifen in rat resulted in the appearance of abnormal hair follicles, epidermal atrophy and increased dermal fibrosis, particularly around the hair follicles; in humans, there have been reports of tamoxifen treatment causing diffuse thinning of the hair with moderate receding of the frontal hair line and the development of alopecia on the crown; in organ culture, tamoxifen alone has no effect on human hair shaft elongation, whereas in excess tamoxifen in combination with $17 \beta$-oestradiol eliminated the effect of $17 \beta$-oestradiol, suggesting that tamoxifen can function as an antagonist of oestrogen in the scalp hair follicle [2]. Tamoxifen has also been described as causing repigmentation of a 68 year-old breast cancer patient's grey hair [11]. So far, the available literature points to the ability of SERMs acting as oestrogen agonists in skin, being able to control skin ageing, wound healing and scarring and to their potential use in topical formulations that would avoid the harmful effects associated with systemic hormone replacement therapies [8].

Along with the beneficial effects of SERMs already described on skin healing and ageing, it would be of great interest to ascertain their effects on skin pigmentation. Melanogenesis is a defensive mechanism against excessive exposure of human skin to sunlight, an environmental risk factor for melanoma and skin ageing. This work aims to study, in vitro, the effect on melanin production of tamoxifen and 4-hydroxy-tamoxifen, one of its most bioactive derivatives and to contribute to a more complete understanding of the potential cosmetic use of this SERM.

\section{Materials and methods}

\section{Reagents}

Tamoxifen (Tam) and 4-hydroxy-tamoxifen (4HO-Tam), reduced disodium salt hydrate $\beta$-nicotinamide adenine dinucleotide (NADH), sodium pyruvate, melanin from Sepia officinalis and Trypsin-EDTA solution were purchased from Sigma-Aldrich Chemie GmbH (Buchs, Switzerland). Soluene-350 was obtained from PerkinElmer (Waltham, MA, U.S.A.). Absolute ethanol (EtOH) used as solvent for Tam and $4 \mathrm{HO}-\mathrm{Tam}$, as well as other common chemical reagents used to prepare the buffers, was purchased from Panreac (Barcelona, Spain).

\section{Cells and culture conditions}

Adult normal human epidermal melanocytes (NHEM) and the optimized media for their growth were supplied by Lonza (Lonza Walkersville, Inc, Walkersville, MD, U.S.A.). Cells were maintained in Melanocyte Cell Basal Medium-4 supplemented with calcium chloride, bovine pituitary extract, recombinant human fibroblast growth factor-B, recombinant human insulin, hydrocortisone, phorbol 12-myristate 13-acetate, gentamicin sulphate and amphotericin-B, foetal bovine serum (melanocyte growth medium 4, $\mathrm{MGM}^{\circledR}-4$ ) and endothelin-3 according to the supplier's instructions. Cell culture was established and maintained in $25 \mathrm{~cm}^{2}$ flasks at $37^{\circ} \mathrm{C}$ and $5 \% \mathrm{CO}_{2}$ in a humidified incubator with the recommended starting cell density of 10000 cells $\mathrm{cm}^{-2}$.

\section{NHEM treatment with tamoxifen and 4-hydroxy-tamoxifen}

Normal human epidermal melanocytes were treated with physiological concentrations of the drugs. Two days after seeding passage 3, melanocytes were incubated with $1 \mu \mathrm{M}$ Tam and $0.5 \mu \mathrm{M} 4 \mathrm{HO}-$ Tam for $72 \mathrm{~h}$. As controls, melanocytes without any treatment and melanocytes incubated with $0.1 \% \mathrm{EtOH}$ were plated in parallel. The media was refreshed every $24 \mathrm{~h}$ and collected for further analysis.

\section{Total melanin spectrophotometric evaluation}

The melanin content was quantified with either 300000 cells, plated on Petri dishes $(\varnothing 60 \mathrm{~mm})$, or from the culture media collected at $24 \mathrm{~h}, 48 \mathrm{~h}$ and $72 \mathrm{~h}$. For measuring intracellular melanin, cells were detached and disrupted in one millilitre of $15 \mathrm{mM}$ Tris- $\mathrm{HCl}$ lysis solution, $\mathrm{pH}$ 7.5. A $150 \mu \mathrm{L}$ of either cell lysate or cell culture medium was solubilized in $1350 \mu \mathrm{L}$ of Soluene-350 at $80^{\circ} \mathrm{C}$ for $1 \mathrm{~h}$. The calibration curves were obtained by solubilizing 5,10 , 20, 30, 40, 60, 80, 100, 300 and $500 \mathrm{mg}$ of Sepia melanin in Soluene-350 with $10 \%$ Tris- $\mathrm{HCl}$ or culture medium, depending on sample type, at $80^{\circ} \mathrm{C}$ for $1 \mathrm{~h}[12,13]$. Before measuring the absor- 
bance at $500 \mathrm{~nm}$, samples and standards were centrifuged for $10 \mathrm{~min}$ at $8600 \mathrm{~g}$.

\section{Cytotoxicity evaluation}

The cytotoxicity induced by Tam and 4HO-Tam at the tested concentrations was evaluated by lactate dehydrogenase (LDH) release to the culture medium simultaneously to extruded melanin monitoring. The LDH activity was determined by the decrease in NADH absorbance at $340 \mathrm{~nm}$ during $3 \mathrm{~min}$ at $30^{\circ} \mathrm{C}$, using a microplate reader. The final reaction volume was $300 \mu \mathrm{L}$ consisting in $250 \mu \mathrm{M} \mathrm{NADH}$ and $280 \mu \mathrm{M}$ pyruvate in $50 \mathrm{mM}$ phosphate buffer. $\mathrm{pH}$ 7.4. To measure the intra- and extracellular LDH activity, $45 \mu \mathrm{L}$ of NHEM lysate and $90 \mu \mathrm{L}$ of culture medium were used, respectively. The percentage of $\mathrm{LDH}$ release was expressed as the relation between extracellular activity and total LDH activity.

\section{Determination of cyclic adenosine monophosphate levels}

To assess how NHEM treatment with Tam and 4HO-Tam affects the levels of cytoplasmic cyclic adenosine monophosphate (cAMP), 145000 cells were seeded on 6-well plates and treated as described. After $72 \mathrm{~h}$, cells were collected in $300 \mu \mathrm{L}$ of $100 \mathrm{mM}$ $\mathrm{HCl}$ solution. Cyclic AMP was quantified using a commercial competitive enzyme-linked immunosorbent assay (Cayman Chemical, Ann Arbor, MI, U.S.A.).

\section{Relative gene expression levels determined by real-time PCR}

Total RNA was isolated from 55500 melanocytes, cultured in 12well plates and treated with Tam and 4HO-Tam as described before, using the SV Total RNA Isolation System (Promega Corporation, Fitchburg WI, U.S.A.) according to the manufacturer's instructions. Reverse transcription (RT) was performed with iScript cDNA Synthesis kit (Bio-Rad Laboratories, Lda., Amadora, Portugal), according to the supplied protocol. The reaction was carried out at $25^{\circ} \mathrm{C}$ for $5 \mathrm{~min}, 42^{\circ} \mathrm{C}$ for $60 \mathrm{~min}$ and $85^{\circ} \mathrm{C}$ for $5 \mathrm{~min}$. Realtime PCR was used to determine whether Tam/4HO-Tam were able to affect the expression of catalase gene and several genes overex- pressed in human pigmented hair follicles when compared with grey hair follicles (unpublished results). TaqMan Universal Master Mix II and the pre-designed/pre-formulated primer and probe sets, TaqMan Gene Expression Assays (Table I), were purchased from Applied Biosystems (Foster City, CA, U.S.A.), and the $\Delta \Delta \mathrm{Ct}$ method was applied using as housekeeping gene, the mitochondrial ATPase 6 (MT-ATP6). The PCR amplification was performed according to the manufacturer's instructions on an CFX96 Touch Real-Time PCR Detection System (Bio-Rad Laboratories, Lda.).

\section{Statistical analysis}

The data were expressed as the mean \pm SEM of at least five replicates. A nonparametric analysis was performed: Kruskal-Wallis $H$-test or Friedman test for repeated measures along time. When $P$-values were equal or inferior to 0.05 , the differences were considered significant. Whenever the Kruskal-Wallis $H$-test led to significant results, Mann-Whitney U-test was performed for sample contrasts between individual sample sets at 0.05 level of risk. All the statistical analysis was performed using Minitab 16 version 16.1.0 ( Minitab Inc., State College, PA, U.S.A.).

\section{Results and discussion}

In the present work, we studied the effect of tamoxifen and 4hydroxy-tamoxifen on melanin production. For this purpose, normal human epidermal melanocytes (NHEM) were incubated with $0.1 \%(\mathrm{v} / \mathrm{v})$ ethanol solutions of tamoxifen (Tam) and 4-hydroxytamoxifen (4HO-Tam) at concentrations in physiological range as determined in patients' serum under tamoxifen treatment [14]. The cells were exposed during three days with medium renewal every $24 \mathrm{~h}$. Total melanin was quantified by spectrophotometry. After performing a calibration curve, the average intracellular melanin content of control NT after $72 \mathrm{~h}$ was determined as $540 \mathrm{ng} \mu \mathrm{g}^{-1}$ of protein. The obtained results were expressed as a ratio of normalized melanin amount having the control NT as divisor (Fig. 1). A trend was observed in the amount of intracellular melanin; melanocytes exposed to Tam and 4HO-Tam produced significantly more melanin than the controls, although ethanol alone (Control

Table I List of TaqMan assays used and respective targets of amplification

\begin{tabular}{|c|c|c|c|}
\hline TaqMan assay & Gene symbol & Protein name & Function (GeneCards) \\
\hline Hs00156308_m1 & CAT & Catalase & Protection of cells from the toxic effects of hydrogen peroxide \\
\hline Hs00167051_m1 & TYRP1 & Tyrosinase-related protein 1 & $\begin{array}{l}\text { Melanosomal enzyme that belongs to the tyrosinase family and plays an important role in } \\
\text { the melanin biosynthetic pathway }\end{array}$ \\
\hline Hs00173854_m1 & SILV & Premelanosome protein & $\begin{array}{l}\text { Melanocyte-specific type I transmembrane glycoprotein (PMEL17) involved in the maturation } \\
\text { of melanosomes from stage I to II }\end{array}$ \\
\hline Hs00194133_m1 & MLANA & Melan-A (MART-1) & $\begin{array}{l}\text { Vital role in the expression, stability, trafficking and processing of melanocyte protein } \\
\text { PMEL17 }\end{array}$ \\
\hline Hs01385410_m1 & SLC24A5 & Solute carrier family 24, member 5 & $\begin{array}{l}\text { Cation exchanger involved in pigmentation, possibly by participating in ion transport in } \\
\text { melanosomes }\end{array}$ \\
\hline Hs01099965_m1 & TYR & Tyrosinase & $\begin{array}{l}\text { Copper-containing oxidase that functions in the formation of pigments such as melanins } \\
\text { and other polyphenolic compounds }\end{array}$ \\
\hline Hs00174029_m1 & KIT & $\begin{array}{l}\text { v-kit Hardy-Zuckerman } 4 \text { feline } \\
\text { sarcoma viral oncogene homolog }\end{array}$ & $\begin{array}{l}\text { Type } 3 \text { transmembrane receptor for MGF (mast cell growth factor, also known as stem } \\
\text { cell factor) }\end{array}$ \\
\hline Hs00955621_m1 & $P L X N C 1$ & Plexin $\mathrm{C} 1$ & Transmembrane receptors for semaphorins together they regulate melanocyte adhesion \\
\hline Hs02596862_g1 & MT-ATP6 & $\begin{array}{l}\text { Mitochondrially encoded ATP } \\
\text { synthase } 6\end{array}$ & \\
\hline
\end{tabular}




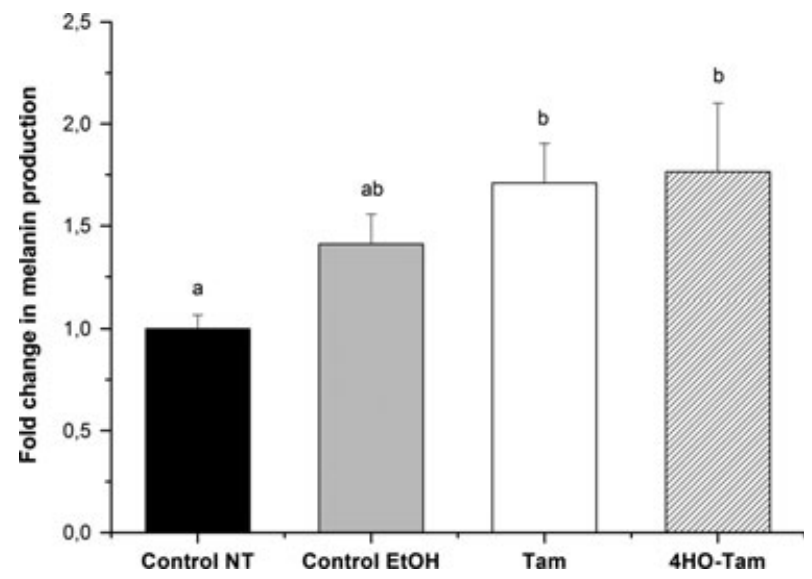

Figure 1 Intracellular melanin after $72 \mathrm{~h}$ of incubation of NHEM with tamoxifen (Tam) and 4-hydroxy-tamoxifen (4HO-Tam) normalized to the total amount of protein and expressed as fold change in melanin in relation to the non-treated (NT) control. The effect of the solvent alone (control $\mathrm{EtOH}$ ) is also shown. Averages that do not share a letter are significantly different according to Kruskal-Wallis $H$-test $(H=8.07$; $\mathrm{DF}=3 ; P=0.045)$ followed by Mann-Whitney U-test as post-hoc test.

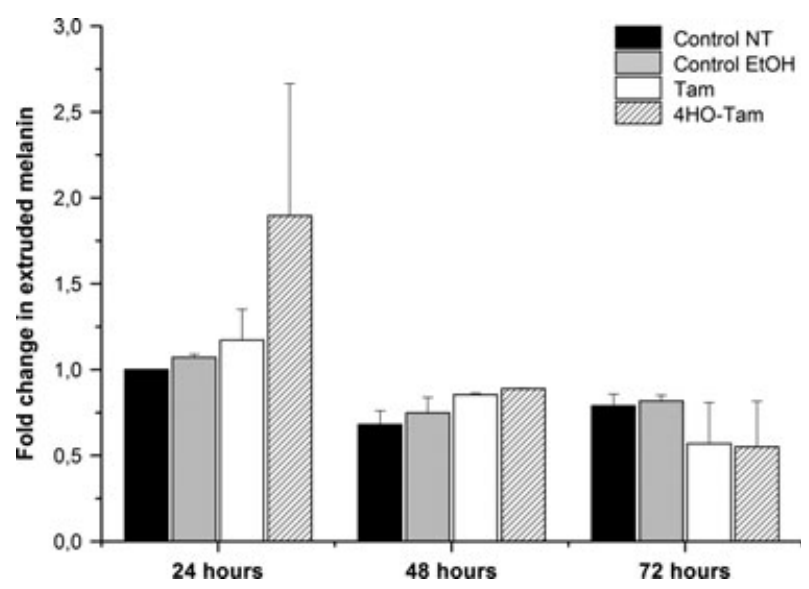

Figure 2 Melanin extruded to the culture medium by NHEM during the incubation with tamoxifen (Tam) and 4-hydroxy-tamoxifen (4HO-Tam); the values are expressed as fold change in relation to melanin levels in non-treated (NT) control after $24 \mathrm{~h}$. The effect of the solvent alone (control EtOH) is also shown. (Friedman test - extruded melanin vs. time grouped by treatment, $S=6.00 ; \mathrm{DF}=2 ; P=0.050)$.

EtOH) was able to induce melanogenesis, to a smaller extent, under this experimental conditions. In a genome-wide siRNA-based functional genomics study of pigmentation, unexpected genes were found to support pigment production through tyrosinase expression and stability [15]. Two of those genes encode two isoforms of aldehyde dehydrogenase, ALDH1A1 and ALDH9A1, which regulate ethanol detoxification. Non-toxic chemical inhibitors of the two ALDH enzymes inhibited pigmentation and tyrosinase protein accumulation in MNT-1 cells, and they impaired UV-induced tyrosinase expression when tested in primary melanocytes [15]. On the other hand, the amount of ethanol solvent present in cell culture med- ium could promote the activity of these detoxifying enzymes and promote melanogenesis in NHEM (Fig. 1).

Skin pigmentation is the result of two major events: the synthesis of melanin by melanocytes and the transfer of melanosomes to the surrounding keratinocytes [16]. Thus, for its biological relevance, melanin extrusion was also evaluated during the incubation of NHEM with Tam and 4HO-Tam (Fig. 2). The results obtained revealed a significant kinetic effect of Tam and mainly 4HO-Tam on melanin extrusion by NHEM. Note that 4HO-Tam accelerated melanin extrusion in the first $24 \mathrm{~h}$, although these levels became similar in all conditions at $48 \mathrm{~h}$ and $72 \mathrm{~h}$.

In normal human cultured melanocytes, physiological concentrations of oestrogens, especially $17 \beta$-oestradiol, were described as enhancers of melanin production (1.25-fold increase) and extrusion (3.4-fold increase after $16 \mathrm{~h}$ ) [5]. The authors also tested the steroid anti-oestrogen ICI 164 384, and they verified that in melanocytes, it also increased tyrosinase activity, behaving as an oestrogen agonist. In the experiment performed, it becomes apparent that Tam and particularly $4 \mathrm{HO}-\mathrm{Tam}$ behave as oestrogen agonists in NHEM by promoting both melanogenesis and melanin extrusion. The fact that the $\mathrm{MGM}^{\circledR}-4$ medium was supplemented with endothelin-3 to enhance the proliferative capacity of melanocyte cultures through serial passages, according to manufacturer instructions, may have diluted the additive response of cells to Tam and 4HO-Tam because the basal levels of control were raised by this hormone (data not shown) [17]. On the other hand, the promelanogenesis effect of tamoxifen may be a long-term effect as reported for the repigmentation of a 68-year-old breast cancer patient's grey hair after two years of tamoxifen treatment [11].

Cell viability was monitored by evaluating cell membrane permeability. The amount of lactate dehydrogenase (LDH) released into the medium was determined in terms of its enzymatic activity and related to the activity in the medium of non-treated (NT) NHEM, after the first $24 \mathrm{~h}$ of incubations (Fig. 3). In all the treatments, the LDH release was under $5 \%$ during the assay period. As expected, the amount of LDH leakage revealed that Tam and 4HOTam had no significant cytotoxic effect at the tested concentrations. Another control was performed bearing the same solvent concen-

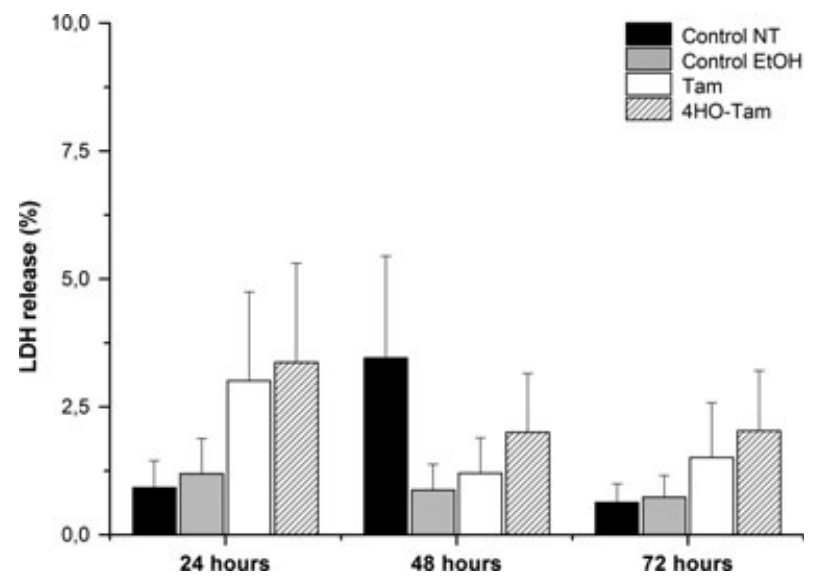

Figure 3 Lactate dehydrogenase (LDH) released into the NHEM culture medium determined as a percentage ratio of enzyme activities. The LDH activity is expressed in relation to the untreated (NT) control after the first $24 \mathrm{~h}$ of the experiment. The effect of the solvent alone (control EtOH) is also shown. No significant differences were detected by the Friedman test. 
tration present in Tam and 4HO-Tam treatments; this control (Control EtOH) also did not affect the NHEM viability (Fig. 3).

Oestrogens regulate biological functions by two distinct mechanisms: a classical pathway that involves the binding to nuclear receptors (ligand-inducible transcription factors) and consequent regulation of the expression of target genes and a non-classical pathway that begins with the oestrogen binding to a membrane receptor followed by rapid intracellular signalling cascades that can eventually lead to gene transcription regulation. In normal human cutaneous melanocytes, the presence of classical oestrogen receptors has been demonstrated by binding studies and using immunocytochemistry and RT-PCR [6, 18]. Although SERMs may act through alternative mechanisms not involving the oestrogen receptor binding, to better elucidate their biological impact, the transcript level of genes of interest should be monitored [19, 20]. The expression of melanogenesis-related genes is crucial to the synthesis of pigments. Hence, in this work, the outcome after $72 \mathrm{~h}$ of Tam and 4HO-Tam treatment on transcription of melanogenesis-related genes in NHEM was evaluated by real-time PCR (Fig. 4). These genes were identified in a microarray study by us (unpublished) as being the most expressed in pigmented vs. grey hair follicles. In NHEM, after $72 \mathrm{~h}$ of treatment, 4HO-Tam in particular up-regulated melanogenesis-related genes transcription even after melanin extrusion peak at $24 \mathrm{~h}$. Even so, the fold change in TYR mRNA induced by $4 \mathrm{HO}-\mathrm{Tam}$ is in the range described by Kippenberger et al. [21], after treating normal human melanocytes with $20 \mu \mathrm{M}$ oestradiol for $48 \mathrm{~h}$. Considering the control $0.1 \%$ ethanol (control $\mathrm{EtOH})$, the effect of $4 \mathrm{HO}-\mathrm{Tam}$ and, to a lesser extent, the effect of Tam were more pronounced for SILV and MLANA genes. PMEL17, also known as gp100 or SILV, is a structural protein essential for the transition from stage I to stage II melanosomes. After its delivery to stage I melanosomes, PMEL17 is cleaved into several fragments, which form the fibrillar matrix of the organelle [22]. In pigmented cells, melanins are deposited on these protein fibres, resulting in a progressively pigmented internal matrix. MART-1, codified by MLANA gene, forms a complex with PMEL17 and affects its post-transcriptional production, stability, trafficking and processing [23]. 4HO-Tam and Tam affect in particular these two

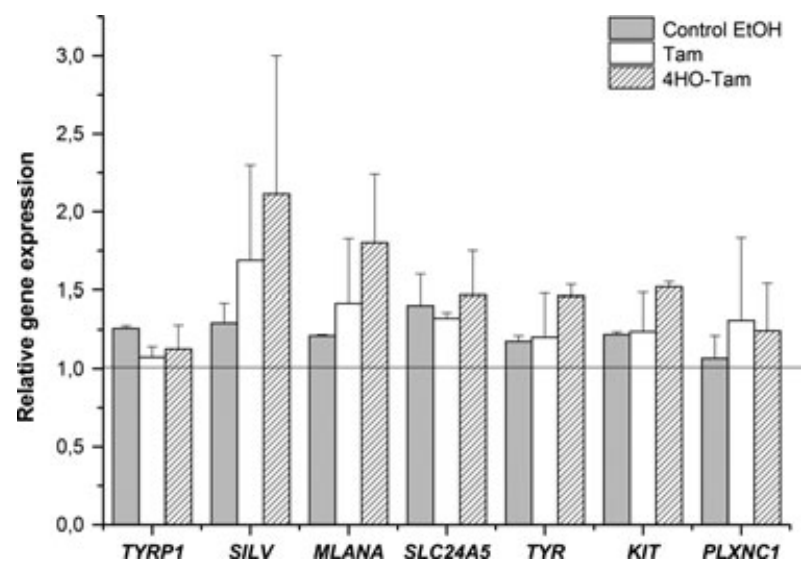

Figure 4 Relative expression of melanogenesis-related genes normalized to transcript levels of housekeeping gene mitochondrial ATPase 6 in NHEM after $72 \mathrm{~h}$ of incubation with tamoxifen (Tam) and 4-hydroxy-tamoxifen (4HO-Tam), determined by real-time PCR using the $\Delta \Delta C$ t method. The effect of the solvent alone (control EtOH) is also shown. No significant differences were detected by the Kruskal-Wallis $H$-test. genes involved in the early maturation of melanosomes. Despite the absence of known diseases associated with these genes, it is possible that some forms of albinism may be linked to PMEL17 deficiency by analogy to the mouse silver mutant [24]. Eventually, these SERMs may be a good starting point for future investigation on therapeutic treatment in heterozygosis disorders involving PMEL17 or MART-1.

To further understand the possible mechanism of action of 4HOTam and Tam in NHEM, the levels of cAMP, a key messenger in melanogenesis, were determined (Fig. 5). The solvent and both Tam and 4HO-Tam significantly decreased the levels of intracellu-

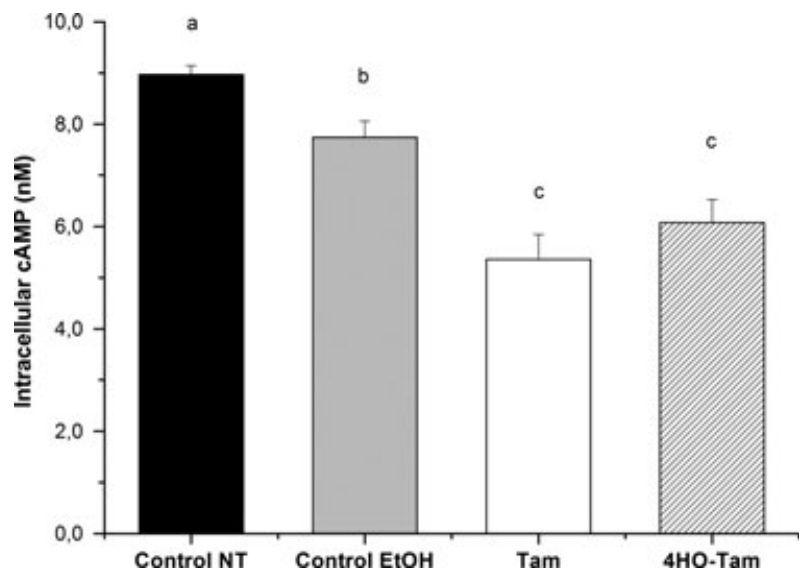

Figure 5 Levels of intracellular cyclic adenosine monophosphate (cAMP) in NHEM after $72 \mathrm{~h}$ of incubation with tamoxifen (Tam) and 4-hydroxy-tamoxifen (4HO-Tam). The effect of the solvent alone (control EtOH) is also shown. Averages that do not share a letter are significantly different according to Kruskal-Wallis $H$-test $(H=22.48$; $\mathrm{DF}=3$; $P<0.001)$ followed by MannWhitney U-test as post-hoc test.

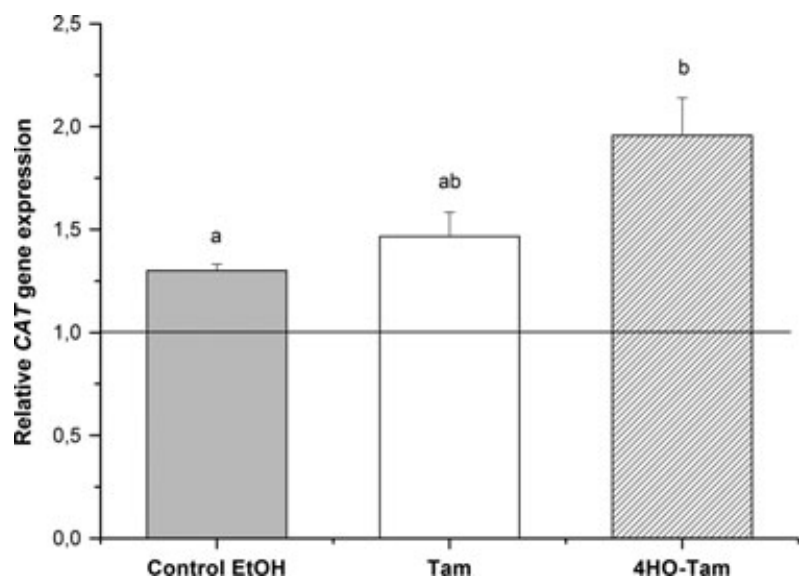

Figure 6 Relative gene expression of catalase normalized to transcript levels of housekeeping gene mitochondrial ATPase 6 in NHEM after $72 \mathrm{~h}$ of incubation with tamoxifen (Tam) and 4-hydroxy-tamoxifen (4HO-Tam), determined by real-time PCR using the $\Delta \Delta \mathrm{Ct}$ method. The effect of the solvent alone (control EtOH) is also shown. Averages that do not share a letter are significantly different according to Kruskal-Wallis $H$-test $(H=6.51 ; \mathrm{DF}=2$; $P=0.039)$ followed by Mann-Whitney $U$-test as post-hoc test. 
lar cAMP. The results have shown that after $72 \mathrm{~h}$, the levels of cAMP are negatively correlated with the levels of intracellular melanin, indicating that the chosen time window, although revealing significant changes in melanin content, did not support the notion that the mechanism of action involves elevation of cAMP levels. In melanocytes, the cAMP/CREB signalling pathway is regulated by melanocyte-stimulating hormone via the G-protein-coupled receptor MC1R, which in turn transcriptionally activates expression of MITF, the master transcriptional regulator of melanocyte development [25]. In vitro and in vivo, the up-regulation of cAMP levels in melanocytes leads to increased pigment production. The magnitude and duration of cAMP action are regulated by both production and hydrolysis. MITF directly regulates the transcription of the phosphodiesterase 4D3, creating negative homoeostatic control of the cAMP pathway to counteract chronic stimulation of the cAMP pathway in melanocytes [26]. Fast response to oestrogens is attributed to membrane oestrogen receptors that trigger rapid increases in cAMP, calcium, extracellular signal-regulated kinase (ERK), signalling pathways all involved in melanogenesis regulation [27]. Tamoxifen and 4HO-Tam are able to bind to G-coupled membrane oestrogen receptor possessing also a non-genomic mechanism of action as oestrogen agonists [28-31].

Melanin synthesis generates hydrogen peroxide $\left(\mathrm{H}_{2} \mathrm{O}_{2}\right)$ and other free radicals making oxidative stress a common theme in melanocyte dysfunction especially relevant for the hair follicle melanocyte population [32]. It was shown in vivo that human grey/white scalp hair shafts accumulate $\mathrm{H}_{2} \mathrm{O}_{2}$ in millimolar concentrations [33]. Melanocytes are sensitive to reactive oxygen species (ROS) due to low catalase levels in these cells. Kauser et al. [34] verified that catalase expression was reduced both in epidermal and hair follicle melanocytes with age, whereas superoxide dismutases remain constant. The outcome of $\mathrm{H}_{2} \mathrm{O}_{2}$ accumulation in melanocytes depends on its concentration $[35,36]$. Millimolar concentrations of $\mathrm{H}_{2} \mathrm{O}_{2}$ can damage many proteins and peptides leading to deactivation/ disruption of many important pathways involved in melanogenesis. However, tyrosinase as well as other proteins are up-regulated and activated by low concentrations of $\mathrm{H}_{2} \mathrm{O}_{2}$ [35]. Consequently, catalase expression/activity is getting increasing attention as a key point for the response of melanocytes to ROS. In human melanocytes in vitro, catalase-specific mRNA, protein and enzymatic activity were directly correlated with total cellular melanin content [37]. Because tamoxifen was described as up-regulating catalase gene transcription and catalase production in aorta of rats after one and two weeks of treatment [38], the influence of Tam and 4HO-Tam on CAT gene mRNA levels of NHEM was determined by real-time PCR (Fig. 6). The levels of CAT mRNA in NHEM were significantly higher upon treatment with 4HO-Tam. Tam and ethanol also induced to some extent the transcription of CAT. A correlation between the up-regulation of CAT transcript levels and intracellular melanin induced by physiological concentrations of the two SERMs tested was verified. Some controversy exists in the literature regarding the putative anti-oxidant role of oestrogens and tamoxifen. Tam promotes superoxide production in platelets increasing the thrombosis risk factor [39], and others describe Tam as being able to reduce the Mn-induced ROS formation in astrocytes [28]. The mechanism must be dependent on the cell type and context; however, if SERMs induce ROS production, they can, depending on the ROS concentrations, activate cellular defensive mechanisms or induce oxidative stress. Under the conditions tested, the 4HO-Tam and Tam at physiological concentrations induced catalase expression in NHEM pointing towards a promelanogenic effect mediated by ROS.

\section{Concluding remarks}

Based on current knowledge on the beneficial effects of topical application of SERMs on skin ageing, there are still many open questions concerning safety, secondary effects and mechanisms of action. The work here reported demonstrated that Tam and its potent metabolite, $4 \mathrm{HO}-\mathrm{Tam}$, have the capacity to induce melanin production and extrusion in normal human melanocytes in vitro, not showing cytotoxicity at physiological concentrations. Melanin itself is a defensive mechanism from photodamage, but uneven pigmentation is undesirable; therefore, further studies must be performed to exclude this hypothesis for topical application of SERMs. The complexity of melanogenesis regulation, which is evident in this work along with other published reports, makes this biological process very hard to modulate exogenously. The mechanism by which these two SERMs act involves changes at the transcript levels of important proteins in the early maturation of melanosomes, PMEL17 and MART-1, and in a newly recognized key melanogenesis modulator - catalase. The capacity of inducing anti-oxidant defensive mechanisms is clearly an advantage of these SERMs from the point of view of an anti-ageing cosmetic use. Our results suggested a possible application of SERMs as non-toxic, anti-oxidant and melanogenic compounds to be used in topic formulations in cosmetic industry.

\section{Acknowledgements}

Teresa Matamá holds a grant from FCT - Fundação para a Ciência e a Tecnologia (SFRH/BPD/47555/2008). This work was supported by FEDER through POFC - COMPETE and by national funds from FCT through the project PEst-C/BIA/UI4050/2011.

\section{References}

1. Emmerson, E. and Hardman, M. J. The role of estrogen deficiency in skin ageing and wound healing. Biogerontology 13, 3-20 (2012).

2. Stevenson, S. and Thornton, J. Effect of estrogens on skin aging and the potential role of SERMs. Clin. Interv. Aging 2, 283-297 (2007).

3. Ohnemus, U., Uenalan, M., Inzunza, J., Gustafsson, J.- $\AA$. and Paus, R. The hair follicle as an estrogen target and source. Endocr. Rev. 27, 677-706 (2006).

4. Creidi, P., Faivre, B., Agache, P., Richard, E., Haudiquet, V. and Sauvanet, J.P. Effect of a conjugated oestrogen $\left(\right.$ Premarin $\left.^{\circledR}\right)$ cream on ageing facial skin. Comparative study with a placebo cream. Maturitas 19, 211-223 (1994).

5. McLeod, S.D., Ranson, M. and Mason, R.S. Effects of estrogens on human melanocytes in vitro. I. Steroid Biochem. Mol. Biol. 49, 914 (1994)
6. Jee, S.-H., Lee, S.-Y., Chiu, H.-C., Chang, C.-C. and Chen, T.J. Effects of estrogen and estrogen receptor in normal human melanocytes. Biochem. Biophys. Res. Commun. 199. 1407-1412 (1994).

7. Schwahn, D.J., Timchenko, N.A., Shibahara, S. and Medrano, E.E. Dynamic regulation of the human dopachrome tautomerase promoter by MITF, ER- $\alpha$ and chromatin remodelers during proliferation and senescence of human melanocytes. Pigment Cell Res. 18, 203-213 (2005). 
8. Shu, Y.Y. and Maibach, H.I. Estrogen and skin: therapeutic options. Am. J. Clin. Dermatol. 12, 297-311 (2011)

9. Archer, D.F. Postmenopausal skin and estrogen. Gynecol. Endocrinol. 28, 2-6 (2012).

10. Singh, M.N., Stringfellow, H.F., Paraskevaidis, E., Martin-Hirsch, P.L. and Martin, F.L. Tamoxifen: important considerations of multifunctional compound with organ-specific properties. Cancer Treat. Rev. 33, 91100 (2007).

11. Seckin, D. and Yildiz, A. Repigmentation and curling of hair after acitretin therapy. Aust. J. Dermatol. 50, 214-216 (2009).

12. Ozeki, H., Ito, S., Wakamatsu, K. and Hirobe, T. Chemical characterization of hair melanins in various coat-color mutants of mice. J. Invest. Dermatol. 105, 361-366 (1995).

13. Kronstrand, R., Förstberg-Peterson, S., KÅgedal, B., Ahlner, J. and Larson, G. Codeine concentration in hair after oral administration is dependent on melanin content. Clin. Chem. 45, 1485-1494 (1999).

14. Vitseva, O., Flockhart, D.A., Jin, Y., Varghese, S. and Freedman, J.E. The effects of tamoxifen and its metabolites on platelet function and release of reactive oxygen intermediates. J. Pharmacol. Exp. Ther. 312 , 1144-1150 (2005).

15. Ganesan, A. K., Ho, H., Bodemann, B. et al. Genome-wide siRNA-based functional genomics of pigmentation identifies novel genes and pathways that impact melanogenesis in human cells. PLoS Genet. 4, e1000298 (2008).

16. Costin, G.E. and Hearing, V.J. Human skin pigmentation: melanocytes modulate skin colour in response to stress. FASEB J. 21, 976-994 (2007).

17. Reid, K., Turnley, A.M., Maxwell, G.D., Kurihara, Y., Kurihara, H., Bartlett, P.F. and Murphy, M. Multiple roles for endothelin in melanocyte development: regulation of progenitor number and stimulation of differentiation. Development 122, 3911-3919 (1996).

18. Im, S., Lee, E.-S., Kim, W., On, W., Kim, J., Lee, M. and Kang, W.H. Donor specific response of estrogen and progesterone on cultured human melanocytes. J. Korean Med. Sci.. 17, 58-64 (2002).

19. Colletta, A.A., Benson, J.R. and Baum, M. Alternative mechanisms of action of anti- oestrogens. Breast Cancer Res. Treat. 31, 5-9 (1994).

20. Nelson, E.R., Wardell, S.E. and McDonnell, D.P. The molecular mechanisms underlying the pharmacological actions of estrogens, SERMs and oxysterols: implications for the treatment and prevention of osteoporosis. Bone 53, 42-50 (2013).

21. Kippenberger, S., Loitsch, S., Solano, F., Bernd, A. and Kaufmann, R. Quantification of tyrosinase, TYRP-1, and TYRP-2 transcripts in human melanocytes by reverse transcriptase-competitive multiplex PCR-regulation by steroid hormones. J. Invest. Dermatol. 110, 364-367 (1998).

22. Berson, J.F., Harper, D.C., Tenza, D., Raposo, G. and Marks, M.S. Pmel17 initiates premelanosome morphogenesis within multivesicular bodies. Mol. Biol. Cell 12, 3451-3464 (2001).

23. Hoashi, T., Watabe, H., Muller, J., Yamaguchi, Y., Vieira, W.D. and Hearing, V.J. MART-1 is required for the function of the melanosomal matrix protein PMEL17/ GP100 and the maturation of melanosomes. J. Biol. Chem. 280, 14006-14016 (2005).

24. Theos, A.C., Truschel, S.T., Raposo, G. and Marks, M.S. The Silver locus product Pmel17/gp100/Silv/ME20: controversial in name and in function. Pigment Cell Res. 18, 322-336 (2005)

25. Lin, J.Y. and Fisher, D.E. Melanocyte biology and skin pigmentation. Nature 445, 843850 (2007)

26. Khaled, M., Levy, C. and Fisher, D.E. Control of melanocyte differentiation by a MITFPDE4D3 homeostatic circuit. Genes Dev. 24, 2276-2281 (2010).

27. Barton, M. Position paper: the membrane estrogen receptor GPER - Clues and questions. Steroids 77, 935-942 (2012).

28. Lee, E.-S.Y., Yin, Z., Milatovic, D., Jiang, H. and Aschner, M. Estrogen and tamoxifen protect against Mn-induced toxicity in rat cortical primary cultures of neurons and astrocytes. Toxicol. Sci. 110, 156-167 (2009).

29. Vivacqua, A., Bonofiglio, D., Albanito, L. et al. $17 \beta$-Estradiol, genistein, and 4-hydroxytamoxifen induce the proliferation of thyroid cancer cells through the g proteincoupled receptor GPR30. Mol. Pharmacol. 70, 1414-1423 (2006).

30. Kanda, N. and Watanabe, S. $17 \beta$-Estradiol stimulates the growth of human keratino- cytes by inducing cyclin D2 expression. J. Invest. Dermatol. 123, 319-328 (2004).

31. Filardo, E.J., Quinn, J.A., Frackelton, A.R. Jr and Bland, K.I. Estrogen action via the G protein-coupled receptor, GPR30: stimulation of adenylyl cyclase and cAMP-mediated attenuation of the epidermal growth factor receptor-to-MAPK signalling axis. Mol. Endocrinol. 16, 70-84 (2002).

32. Arck, P.C., Overall, R., Spatz, K. et al. Towards a "free radical theory of graying": melanocyte apoptosis in the aging human hair follicle is an indicator of oxidative stress induced tissue damage. FASEB J. 20, E908E920 (2006).

33. Wood, J.M., Decker, H., Hartmann, H. et al. Senile hair graying: $\mathrm{H}_{2} \mathrm{O}_{2}$-mediated oxidative stress affects human hair color by blunting methionine sulfoxide repair. FASEB J. 23, 2065-2075 (2009).

34. Kauser, S., Westgate, G.E., Green, M.R. and Tobin, D.J. Human hair follicle and epidermal melanocytes exhibit striking differences in their aging profile which involves catalase. J. Invest. Dermatol. 131, 979-982 (2011).

35. Schallreuter, K.U., Kothari, S., Chavan, B. and Spencer, J.D. Regulation of melanogenesis - controversies and new concepts. Exp. Dermatol. 17, 395-404 (2007).

36. Schallreuter, K.U., Salem, M.M.A.E.L., Hasse, S. and Rokos, H. The redox - biochemistry of human hair pigmentation. Pigment Cell Melanoma Res. 24, 51-62 (2011).

37. Maresca, V., Flori, E., Briganti, S. et al. Correlation between melanogenic and catalase activity in in vitro human melanocytes: a synergic strategy against oxidative stress. Pigment Cell Melanoma Res. 21, 200-205 (1996).

38. Grigoryants, V., Hannawa, K.K., Pearce, C.G. et al. Tamoxifen up-regulates catalase production, inhibits vessel wall neutrophil infiltration, and attenuates development of experimental abdominal aortic aneurysms. J. Vasc. Surg. 41, 108-114 (2005).

39. Shah, V.P., Chegini, H.A., Vishneski, S.R., Weatherman, R.V., Blackmore, P.F. and Dobrydneva, Y. Tamoxifen promotes superoxide production in platelets by activation of PI3-Kinase and NADPH oxidase pathways. Thromb. Res. 129, 36-42 (2012). 